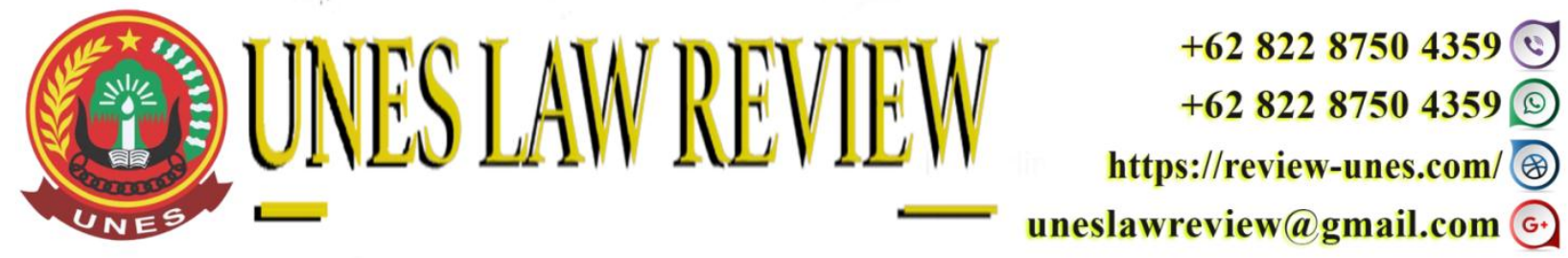

DOI: https://doi.org/10.31933/unesrev.v3i2

Diterima: 25/01/2021, Diperbaiki: 05/02/2021, Diterbitkan: 18/02/2021

\title{
PEMBERIAN TANAH KEPADA SESEORANG SEBAGAI SOLUSI DALAM MENGATASI KELALAIAN AHLI WARIS
}

\section{Devirianti Effendi}

Fakultas Hukum, Universitas Ekasakti, Padang, Indonesia

Email: deviriantieffendi69@gmail.com

Corresponding Author: Devirianti

\section{ABSTRACT}

The Indonesian state, which has the concept of the relationship between humans and land, is an individual and society as an inseparable unity (duality), that the fulfillment of one's needs for the land is placed within the framework of the needs of the whole community, so that the relationship is not merely individualistic, but rather collective while still providing place and respect for individual rights. Land management by the government, where the land registered in the territory of Indonesia will give a legal claim to the tutorial of the Republic of Indonesia (NKRI) in full. In addition, it is also to strengthen a harmonious national life by minimizing land dispute conflicts. This research is descriptive in nature, using a normative juridical approach. Data Analysis and Presentation, the data that has been obtained, both primary and secondary data, were analyzed using qualitative methods, namely by grouping data according to the aspects studied and conclusions that are relevant to the issues discussed. It is hoped that in the implementation of this gift, the related government will further improve services in terms of process and completion time. This is because there are many processes that must be passed in registering land. Where in the implementation of this transfer of land rights must go through several related agencies. It is hoped that the government will be more aggressive in providing awareness to the community by providing education on the legality of their lands and proof of their ownership so that there will be no future disputes. Providing knowledge to the wider community, especially the people of Padang City, of the completeness and correctness of their population data (such as the correctness of the data on their KTP), the completeness and correctness of their property data (one of which is their SPPT PBB).

Kata Kunci: Pemberian Tanah, Kelalaian, Ahli Waris

\section{PENDAHULUAN}

Pesatnya pertumbuhan penduduk saat ini dapat menyebabkan tanah bersifat langka dan terbatas, terkadang tanah juga merupakan hal yang sangat rawan serta berpotensi pemicu krisis sosial. Hal ini menyebabkan pentingnya peranan Negara untuk mengatur tanah-tanah yang berada dalam wilayah kekuasaannya agar mempunyai tujuan yang hendak dicapai. Negara 
Indonesia yang memiliki konsep hubungan antara manusia dengan tanah merupakan individu dan masyarakat sebagai kesatuan yang tak terpisahkan (kedwitunggalan), bahwa pemenuhan kebutuhan seseorang terhadap tanah diletakkan dalam kerangka kebutuhan seluruh masyarakat, sehingga hubungannya tidak bersifat individualism semata, tetapi lebih bersifat kolektif dengan tetap memberikan tempat dan penghormatan terhadap hak perorangan.

Republik Indonesia, yang susunan kehidupan rakyatnya, termasuk perekonomiannya, terutama masih bercorak agrarian, bumi, air dan ruang angkasa, sebagai karunia Tuhan Yang Maha Esa mempunyai fungsi yang amat penting untuk membangun masyarakat yang adil dan makmur seperti yang kita cita-citakan. Menurut ketentuan Pasal 33 ayat (3) Undang-undang Dasar Negara Republik Indonesia Tahun 1945, menyatakan bahwa : "Bumi, air dan kekayaan alam yang terkandung di dalamnya, dikuasai oleh negara dan dipergunakan sebesar-besarnya bagi kemakmuran rakyat".

Pasal tersebut mengandung maksud bahwa bumi, air dan kekayaan alam yang terkandung di dalamnya, adalah pokok-pokok kemakmuran rakyat. Oleh karena itu, pengaturan dan pemanfaatannya harus dikuasai oleh Negara dan dipergunakan sebesar-besarnya bagi kemakmuran rakyat. Untuk mencapai apa yang ditentukan dalam Pasal 33 ayat (3) Undangundang Dasar Negara Republik Indonesia Tahun 1945, tidak perlu dan tidaklah pula pada tempatnya, bahwa bangsa Indonesia ataupun Negara bertindak sebagai pemilik tanah.

Pada tanggal 24 September 1960, disahkan Undang-undang Nomor 5 Tahun 1960 tentang Peraturan Dasar Pokok-pokok Agraria. Undang-undang ini lebih dikenal dengan sebutan Undang-undang Pokok Agraria (UUPA). Tujuan diundangkan Undang-undang Pokok Agraria (UUPA) sebagaimana yang termuat dalam Penjelasan Umumnya, yaitu :

1. Meletakkan dasar-dasar bagi penyusunan hukum agraria nasional, yang merupakan alat untuk membawakan kemakmuran, kebahagiaan dan keadilan bagi Negara dan rakyat, terutama rakyat tani, dalam rangka masyarakat adil dan makmur.

2. Meletakkan dasar-dasar untuk mengadakan kesatuan dan kesederhanaan dalam hukum pertanahan.

3. Meletakkan dasar-dasar untuk memberikan kepastian hukum mengenai hak-hak atas tanah bagi rakyat seluruhnya.

Berkaitan dengan hal tersebut dalam Pasal 2 ayat (1) UUPA menyatakan bahwa : "Atas dasar ketentuan dalam Pasal 33 ayat (3) Undang-undang Dasar Negara Republik Indonesia Tahun 1945 dan hal-hal sebagaimana yang dimaksud dalam Pasal 1, bumi, air dan ruang angkasa, termasuk kekayaan alam yang terkandung di dalamnya itu pada tingkatan tertinggi dikuasai oleh negara, sebagai organisasi kekuasaan seluruh rakyat”.

Pengelolaan tanah oleh pemerintah, dimana tanah-tanah yang terdaftar di wilayah Indonesia akan memberikan klaim legal atas tutorial Negara Kesatuan Republik Indonesia (NKRI) secara utuh. Selain itu, juga untuk memantapkan kehidupan berbangsa yang harmoni dengan meminimalisasi konflik sengketa tanah. Bagi masyarakat sendiri, tanah yang terdaftar akan memberikan jaminan kepastian hukum atas tanah. Sistem pendaftaran tanah sendiri tidak terlepas dari sudut pandang administrasi dan hukum baik perdata maupun tata usaha negara. Secara tersirat, sistem pendaftaran tanah yang akan diwujudkan dalam UUPA adalah sistem pendaftaran tanah positif, karena untuk kepentingan kepastian hukum atas tanah-tanah yang terdaftar (Waskito, Hadi Arnowo, 2019:3).

Objek pendaftaran tanah pasti diasosiasikan pada permukaan bumi atau tanah. Kemajuan konstruksi saat ini memunculkan pusat perbelanjaan di ruang bawah dan ruang atas tanah. Selain 
itu, dimungkinkan ruang bawah dan ruang atas permukaan air. Di ruang bawah dan atas permukaan tanah dan permukaan air akan terdiri dari unit-unit yang dapat dihuni atau untuk penggunaan lain. Setiap unit-unit yang dapat diberikan tanda bukti hak sehingga memerlukan ketentuan tersendiri mengenai pendaftaran tanahnya. Pendaftaran tanah jauh lebih kompleks dan mengandung potensi pendaftaran properti benda-benda bergerak. Properti tanah memiliki keunikan, yaitu benda berharga yang tidak diproduksi dan tidak bertambah, kebutuhan semakin meningkat dan sangat dipengaruhi oleh sosial budaya setempat.

Tanah-tanah yang belum terdaftar masih dominan sehingga menjadi prioritas pemerintah untuk menyelesaikan pendaftaran tanah di seluruh wilayah Indonesia. Tanah-tanah yang belum terdaftar harus melalui pembuktian untuk dapat diberikan tanda bukti hak berupa sertifikat. Pembuktian hak dilakukan dengan meneliti, mengumumkan dan menetapkan hak. Mengingat beragamnya dokumen dan riwayat penguasaan tanah, maka pembuktian hak terbagi atas pembuktian hak-hak lama dan pembuktian hak-hak baru. Adapun jenis-jenis peralihan hak dinyatakan pada Pasal 37 ayat (1) PP Nomor 24 Tahun 1997.

Bagi masyarakat yang awam terhadap hukum, segala permasalahan tentang tanah dan kepemilikannya terasa rumit. Terbukti dari banyaknya kasus sengketa tanah yang semakin hari semakin banyak. Sebenarnya, kasus sengketa tanah baik yang ringan maupun yang berat atau rumit bisa diselesaikan dengan baik dan tentunya sesuai dengan prosedur. Diharapkan masingmasing pihak mengerti hukum dan mempunyai kemauan untuk menyelesaikan segala persoalan tentang tanah sesuai hukum yang berlaku. Jika tidak, akan ada banyak pihak yang merasa dirugikan.

Bila kita melihat lebih jauh lagi tentang Pemberian, atau pemberian dalam hal ini sebenarnya termasuk dalam pengertian hukum, karena mempunyai ketentuan-ketentuan hukum sendiri. Pada umumnya proses beri memberi itu terjadi secara terpisah, yaitu tidak terjadi saat yang bersamaan, melainkan ada tenggang waktu tertentu sesuai dengan suasana saat itu. Sifat dari pemberian itu adalah umum, karena baik pemberi maupun penerima Pemberian tidak perlu memenuhi kewajiban tertentu.

Jika orang perseorangan selaku subyek hak atas tanah, yaitu setiap orang yang identitasnya terdaftar selaku Warga Negara Indonesia, berdomisili di wilayah Negara Indonesia dan tidak kehilangan hak memperoleh sesuatu hak atas tanah. Namun untuk melakukan tindakan hukum dalam hal pertanahan harus sudah dewasa secara hukum. Subyek hukum yang tidak sempurna, adalah orang-orang yang belum dewasa. Menurut Pasal 330 Kitab Undang-undang Hukum Perdata, mereka yang belum mencapai umur 21 tahun dan belum pernah kawin sebelumnya, sedangkan wanita dalam perkawinan sejak dikukuhkan SEMA Nomor 13 Tahun 1963, maka kedudukan wanita dalam perkawinan dianggap cakap menurut hukum, hal ini sesuai dengan ketentuan Pasal 31 Undang-undang Nomor 1 Tahun 1974 tentang Perkawinan. Hukum Perdata berangkat dari prinsip, bahwa untuk pemenuhan dan pelaksanaan kepentingannya, kepada person diberikan kebebasan untuk bertindak menurut kehendaknya, khususnya atas harta kekayaannya.

Mereka pada asasnya diberi kebebasan untuk mengambil tindakan kepemilikan atasnya. Terhadap kebebasan tersebut, pembuat undang-undang memberikan pembatasan-pembatasan antara lain yang berkaitan dengan faktor umur, yang mengandung unsur perlindungan. Kesemuanya itu berkaitan dengan masalah kecakapan bertindak dalam hukum. Untuk menerima suatu hak, diperbolehkan orang itu belum dewasa, tetapi ia harus diwakili oleh orang tua atau walinya. Wali disini mempunyai fungsi mengurus kekayaan anak yang berada di bawah pengawasannya dengan sebaik-baiknya, dan bertanggung jawab tentang kerugian-kerugian yang 
ditimbulkan karena kepengurusan yang buruk. Dalam lalu lintas hubungan keperdataan yang timbul dari perbuatan hukum perdata terjadi juga peralihan hak dari subyek hukum yang satu ke subyek hukum yang lainnya. Peralihan hak itu baik menyangkut benda-benda bergerak maupun benda yang tidak bergerak, seperti tanah dan bangunan yang ada di atasnya.

Adapun bentuk-bentuk peralihan hak yang terjadi melalui perbuatan hukum perdata itu antara lain adalah jual beli, baik biasa maupun secara lelang, tukar menukar, waris dan Pemberian. Mengenai Pemberian dewasa ini disamping berlaku ketentuan-ketentuan Hukum Adat pada masing-masing daerah, juga berlaku secara nasional Hukum Islam yang dituangkan pengaturannya dalam Kompilasi Hukum Islam (KHI) dan Kitab Undang-undang Hukum Perdata yang merupakan peninggalan Belanda yang disebut Burgerlijke Wetboek (BW).

Secara sederhana, Pemberian dapat diartikan sebagai pemberian cuma-cuma dari si pemberi Pemberian kepada si penerima Pemberian. Dalam Pasal 1666 Kitab Undang-undang Hukum Perdata dirumuskan secara yuridis defenisi Pemberian itu. Undang-undang hanya mengakui pengPemberian an itu bagi orang yang masih hidup. Pemberian akan benda bergerak seperti kendaraan bermotor, alat-alat elektronik, furniture dan lain-lain, yang peralihan haknya tidak memerlukan syarat-syarat publik tidaklah menjadi hal yang rumit dalam perbuatan hukum perdata.

Tetapi jika yang diPemberian kan itu adalah benda tidak bergerak seperti tanah dan rumah, pelaksanaannya harus mengindahkan ketentuan undang-undang yang syarat formilnya bersifat publik, yaitu harus dilakukan di hadapan Notaris. Khusus tanah di hadapan Pejabat Pembuat Akta Tanah (PPAT) yang dapat dirangkap oleh Notaris. Di kota Padang sendiri, terjadi juga Pemberian terhadap benda tidak bergerak dimana obyeknya adalah tanah, baik itu tanah pertanian maupun lahan tempat tinggal.

Berdasarkan uraian di atas, maka permasalahan yang dibahas dalam penulisan artikel ini adalah :

1. Bagaimanakah pelaksanaan peralihan hak milik atas tanah melalui pemberian kepada Seseorang merupakan solusi dalam mengatasi kelalaian ahli waris?

2. Apa saja kendala-kendala dalam proses pelaksanaan peralihan hak milik atas tanah melalui pemberian kepada Seseorang merupakan solusi dalam mengatasi kelalaian ahli waris?

\section{METODE PENELITIAN}

Spesifikasi penelitian yang bersifat deskriptif, yaitu penelitian yang memberikan gambaran tentang pelaksanaan peralihan hak milik atas tanah melalui pemberian Sukarela yang dilakukan sebagai solusi dalam mengatasi kelalaian ahli waris. Dalam usaha yang dilakukan untuk mendapatkan data yang diinginkan dan untuk mendapatkan hasil, penulis menggunakan metode pendekatan yuridis normatif dimana penulis mempelajari peraturan perundangundangan, mengenai prosedur pelaksanaan peralihan hak milik atas tanah tersebut.

Data-data yang telah diperoleh baik itu data primer ataupun data sekunder, dianalisis menggunakan metode kualitatif, yaitu dengan cara mengelompokkan data menurut aspek-aspek yang diteltiti dan ditarik kesimpulan yang relevan dengan masalah yang dibahas. 


\section{HASIL DAN PEMBAHASAN \\ HASIL}

\section{Tanah Sebagai Bagian dari Agraria Dalam Arti Luas}

Istilah tanah (agraria) berasal dari beberapa bahasa. Akker (bahasa Belanda), agros (bahasa Yunani), agger (bahasa Latin) yang berarti tanah atau sebidang tanah. Agrarius (bahasa Latin) berarti persawahan, perladangan, dan pertanian. Menurut kamus besar Bahasa Indonesia, agraria berarti urusan pertanahan atau tanah pertanian juga urusan pemilikan tanah, dalam bahasa inggris, agraria selalu diartikan tanah dan dihubungkan dengan usaha pertanian. Sedangkan dalam UUPA mempunyai arti sangat luas, yaitu meliputi bumi, air dan dalam batasbatas tertentu juga ruang angkasa serta kekayaan alam yang terkandung didalamnya. Johara $\mathrm{T}$. Jaya Dinata, (1999:1) mengatakan :

Tanah sebagai salah satu sumber produksi, bagi kebanyakan orang juga merupakan sumber status yang penting untuk menunjukkan "keberadaan" seseorang. Semakin banyak bidang tanah yang dimiliki maka menunjukkan pula bahwa orang tersebut semakin berada atau kaya dan dihormati oleh orang lain. Akibat tanah sebagai simbol status, maka setiap orang selalu menginginkan tanah yang luas, bidang tanah yang lebih banyak dan terletak strategis. Simbol status ini, menjadikan salah satu motif mendorong orang untuk menguasai tanah lebih banyak.

Undang-undang Nomor 5 Tahun 1960 tentang Peraturan Dasar Pokok-pokok Agraria (UUPA) tidak memberikan pengertian mengenai apa itu agraria, namun hanya memberikan ruang lingkup agraria yang dapat dilihat dalam konsideran, rumusan pasal-pasalnya, dan penjelasannya. Ruang lingkup agraria menurut Undang-undang Nomor 5 Tahun 1960 atau yang lebih dikenal dengan UUPA meliputi bumi yang terdapat dalam Pasal 1 ayat (4), air terdapat pada Pasal 1 ayat (5), ruang angkasa di dalam Pasal 1 ayat (6), dan kekayaan alam yang terkandung di dalamnya.

Hukum agraria dapat dikatakan sebagai keseluruhan kaidah hukum baik tertulis maupun tidak tertulis yang mengatur mengenai agraria. Hukum tanah sendiri merupakan keseluruhan kaidah hukum (tertulis dan tidak tertulis) yang mengatur hak-hak penguasaan atas tanah. Tanah yang dimaksud bukanlah tanah dalam segala aspeknya, melainkan hanya mengenai aspek yuridisnya, yaitu hak. Obyek hukum tanah adalah hak penguasaan atas tanah. Hak penguasaan atas tanah merupakan hak yang berisi serangkaian wewenang, kewajiban, dan/atau larangan bagi pemegang haknya untuk berbuat sesuatu mengenai tanah yang dihakinya.

Tanah sebagai bagian dari bumi diatur dalam Pasal 4 ayat (1) Undang-Undang Nomor 5 Tahun 1960 atau dikenal dengan UUPA, menyatakan bahwa:

"Atas dasar hak menguasai dari Negara sebagai yang dimaksud dalam Pasal 2 ditentukan adanya macam-macam hak atas permukaan bumi, yang disebut tanah, yang dapat diberikan kepada dan dipunyai oleh orang-orang, baik sendiri maupun bersama-sama dengan orang-orang lain serta badan-badan hukum."

Ruang lingkup agraria menurut UUPA sama dengan ruang lingkup sumber daya agrarian/sumber daya alam menurut Ketetapan MPR RI Nomor IX/MPR/2001 tentang 
Pembaruan Agraria dan Pengelolaan Sumber Daya Alam. Ruang lingkup agraria/sumber daya agraria/sumber daya alam dapat dijelaskan sebagai berikut :

1. Bumi.

2. Air

3. Ruang angkasa

4. Kekayaan alam yang terkandung di dalamnya

Kekayaan alam yang terkandung di dalam bumi disebut bahan, yaitu unsur-unsur kimia, mineral, bijih-bijih dan segala macam bebatuan, termasuk batuan-batuan mulia yang merupakan endapan-endapan alam (Undang-undang Nomor 1 Tahun 1967 tentang Ketentuan-ketentuan Pokok Pertambangan).

Pengertian agraria dalam arti sempit hanyalah meliputi permukaan bumi yang disebut tanah. Sedangkan pengertian agraria dalam arti luas meliputi bumi, air, ruang angkasa, dan kekayaan alam yang terkandung di dalamnya. Pengertian tanah yang dimaksud disini bukan dalam pengertian fisik, melainkan tanah dalam pengertian yuridis, yaitu hak. Pengertian agraria yang dimuat dalam UUPA adalah pengertian UUPA dalam arti luas.
a. Asas-asas Hukum Agraria
b. Tujuan Hukum Agraria Nasional
c. Hak-hak Penguasaan Atas Tanah
d. Jenis-jenis Hak Tanah

\section{Bentuk-bentuk Hak Atas Tanah}

Dalam Pasal 2 ayat (1) Undang-undang Nomor 5 Tahun 1960 tentang Peraturan Dasar Pokok-pokok Agraria, atau lebih dikenal dengan sebutan Undang-undang Pokok Agraria (UUPA)

Penguasaan atas bumi, air, ruang angkasa, termasuk kekayaan alam yang terkandung di dalamnya oleh Negara dikenal dengan sebutan Hak Menguasai Negara. Pasal 2 ayat (2) UUPA menetapkan bahwa hak menguasai Negara memberi wewenang untuk :

a. Mengatur dan menyelenggarakan peruntukan, penggunaan, persediaan, dan pemeliharaan bumi, air, dan ruang angkasa;

b. Menentukan dan mengatur hubungan-hubungan hukum antara orang-orang dengan bumi, air, dan ruang angkasa; serta

c. Menentukan dan mengatur hubungan-hubungan hukum antara orang-orang dan perbuatan-perbuatan hukum yang mengenai bumi, air, dan ruang angkasa.

Tujuan hak menguasai negara atas bumi, air, ruang angkasa adalah untuk mencapai sebesar-besarnya kemakmuran rakyat dalam arti kebangsaan, kesejahteraan, dan kemerdekaan dalam masyarakat dan negara hukum Indonesia yang merdeka, berdaulat, adil, dan makmur. Hak menguasai negara atas bumi, air, dan ruang angkasa dalam pelaksanaannya dapat dikuasakan kepada daerah-daerah swatantra (pemerintah daerah) dan masyarakat-masyarakat hukum adat sekedar diperlukan dan tidak bertentangan dengan kepentingan nasional menurut ketentuan- 
ketentuan Peraturan Pemerintah. Dasar hukum ketentuan hak-hak atas tanah diatur dalam Pasal 4 ayat (1) UUPA, yaitu :

"Atas dasar hak menguasai dari Negara sebagai yang dimaksud dalam Pasal 2 ditentukan adanya macam-macam hak atas permukaan bumi, yang disebut tanah, yang dapat diberikan kepada dan dipunyai oleh orang-orang, baik sendiri maupun bersama-sama dengan orang-orang lain serta badan-badan hukum."

Hak atas permukaan bumi, yang disebut hak atas tanah bersumber dari hak menguasai Negara atas tanah. Hak atas tanah dapat diberikan kepada dan dipunyai oleh perseorangan, baik warga negara Indonesia ataupun orang asing yang berkedudukan di Indonesia, sekelompok orang secara bersama-sama, dan badan hukum yang didirikan menurut hukum Indonesia dan berkedudukan di Indonesia atau badan hukum asing yang mempunyai perwakilan di Indonesia, badan hukum privat atau badan hukum publik.

Dalam Pasal 16 dan Pasal 53 UUPA, macam-macam hak atas tanah ini dikelompokkan menjadi:

a. Hak atas tanah yang bersifat tetap, yaitu hak-hak atas tanah ini akan tetap ada atau berlaku selama UUPA masih berlaku atau belum dicabut oleh Undang-undang yang baru. Yang termasuk hak ini diantaranya adalah Hak Milik, Hak Guna Usaha, Hak Guna Bangunan, Hak Pakai, Hak Sewa untuk Bangunan, Hak Membuka Tanah, dan Hak Memungut Hasil Hutan.

b. Hak atas tanah yang akan ditetapkan dengan Undang-undang, yaitu hak atas tanah yang akan lahir kemudian yang akan ditetapkan dengan undang-undang.

c. Hak atas tanah yang bersifat sementara, yaitu hak atas tanah yang sifatnya sementara dalam waktu yang singkat akan dihapuskan, dikarenakan mengandung sifat-sifat pemerasan, mengandung sifat feodal (dikuasai oleh penguasa), dan bertentangan dengan jiwa UUPA. Yang termasuk hak atas tanah ini diantaranya adalah Hak Gadai, Hak Usaha Bagi Hasil, Hak Menumpang, dan Hak Sewa Tanah Pertanian.

Dalam sistem UUPA ditentukan bahwa macam hak atas tanah bersifat terbuka, artinya masih terbuka peluang adanya penambahan macam hak atas tanah selain yang ditentukan dalam Pasal 16 ayat (1) UUPA dan Pasal 53 UUPA. Pembentuk UUPA sendiri sudah mengantisipasi bahwa suatu saat kelak akan lahir hak atas tanah baru seiring dengan perkembangan masyarakat dan pembangunan.

Menurut UUPA, berdasarkan asal tanahnya, hak atas tanah dibagi menjadi 2 (dua) kelompok :

a. Hak atas tanah yang bersifat primer, yaitu hak atas tanah yang berasal dari tanah negara. Adapun macam-macam hak atas tanah ini adalah Hak Milik, Hak Guna Usaha, Hak Guna Bangunan atas tanah Negara, dan Hak Pakai atas tanah Negara.

b. Hak atas tanah yang bersifat sekunder, yaitu hak atas tanah yang berasal dari tanah pihak lain. Hak atas tanah ini terdiri dari Hak Guna Bangunan atas tanah Hak Pengelolaan, Hak Guna Bangunan atas tanah Hak Milik, Hak Pakai atas tanah Hak Pengelolaan, Hak Pakai 
atas tanah Hak Milik, Hak Sewa untuk Bangunan, Hak Gadai, Hak Usaha Bagi Hasil, Hak Menumpang, dan Hak Sewa Tanah Pertanian.

Ada 4 (empat) cara terjadinya hak atas tanah menurut peraturan perundang-undangan di bidang pertanahan, yaitu :

a. Hak atas tanah menurut hukum adat.

b. Hak atas tanah terjadi karena penetapan pemerintah.

c. Hak atas tanah terjadi karena ketentuan undang-undang.

d. Hak atas tanah terjadi karena pemberian hak.

Subyek dari Hak Milik atas atas tanah adalah Warga Negara Indonesia dan badan-badan hukum yang ditetapkan oleh pemerintah berdasarkan syarat-syarat dari ketentuan yang berlaku. Hal ini sesuai dengan ketentuan Pasal 21 ayat (1) UUPA yaitu : "Hanya warga negara Indonesia dapat mempunyai hak milik" dan pada ayat (2) yaitu : "Oleh Pemerintah ditetapkan badan-badan hukum yang dapat mempunyai hak milik dan syarat-syaratnya."

Maka berdasarkan hal di atas, dapat kita jabarkan bahwa pihak-pihak yang dapat memiliki ataupun yang dapat mempunyai hak atas tanah adalah :

a. Perseorangan.

b. Badan Hukum

Dari aspek jangka waktu pemilikan atau penguasaannya, hak atas tanah dibagi menjadi 3 (tiga) menurut UUPA, yaitu :

a. Hak atas tanah yang berlaku untuk selama-lamanya (tidak dibatasi oleh jangka waktu).

b. Hak atas tanah yang berlaku untuk jangka waktu tertentu.

Hak atas tanah ini, adalah :

1) Hak Guna Usaha.

2) Hak Guna Bangunan atas tanah Negara.

3) Hak Guna Bangunan atas tanah Hak Pengelolaan.

4) Hak Guna Bangunan atas tanah Hak Milik.

5) Hak Pakai atas tanah Negara.

6) Hak Pakai atas tanah Hak Pengelolaan.

7) Hak Pakai atas tanah Hak Milik.

8) Hak Sewa untuk Bangunan.

c. Hak atas tanah yang berlaku selama tanahnya digunakan untuk keperluan tertentu atau pelaksanaan tugasnya.

Undang-undang Nomor 5 Tahun 1960 (UUPA), Peraturan Pemerintah Nomor 40 Tahun 1996, dan Peraturan Pemerintah Nomor 24 Tahun 1997 menetapkan bahwa hak atas tanah wajib didaftar. Kegiatan pendaftaran tanah untuk pertama kalinya melalui pendaftaran tanah secara sporadik dan pendaftaran tanah secara sistematik menghasilkan surat tanda bukti hak berupa sertifikat. 


\section{Tinjauan Hukum Tentang Peralihan Hak Atas Tanah}

Peralihan hak atas tanah adalah berpindahnya hak atas tanah dari pemegang hak yang lama kepada pemegang hak yang baru. Peraturan Pemerintah No. 24 Tahun 1997 membagi peralihan hak atas tanah dalam beberapa bentuk, yaitu pemindahan hak, pemindahan hak dengan lelang, peralihan hak karena pewarisan hak, peralihan hak karena penggabungan atau peleburan perseroan atau koperasi dan pembebanan hak. Ada 2 (dua) cara peralihan hak atas tanah, yaitu :
a. Beralih
b. Dialihkan

Hak-hak yang dimiliki oleh pemegang hak atas tanah terhadap hak atas tanah, adalah :

a. Mempergunakan tanah dan/atau mengambil manfaat dari tanah.

b. Mewariskan hak atas tanah.

c. Memindahkan hak atas tanah.

d. Membebani hak atas tanah dengan Hak Tanggungan.

e. Melepaskan atau menyerahkan hak atas tanah.

Kewajiban yang harus dipenuhi oleh pemegang hak atas tanah terhadap hak atas tanahnya, yaitu :

a. Mendaftarkan hak atas tanah untuk pertama kalinya.

b. Mendaftarkan peralihan hak atas tanah.

c. Mendaftarkan pembebanan hak atas tanah.

d. Mendaftarkan hapusnya hak atas tanah.

Adapun faktor-faktor yang menjadi penyebab hapusnya hak atas tanah menurut UUPA, yaitu :

a. Tanahnya musnah.

b. Pelepasan atau penyerahan hak atas tanah.

c. Pencabutan hak atas tanah.

d. Tanahnya ditelantarkan.

e. Jangka waktunya berakhir.

f. Subyek haknya tidak memenuhi syarat.

g. Dibatalkan oleh pejabat yang berwenang. Adapun dasar hukum peralihan hak atas tanah, yaitu :

a. Undang-Undang Nomor 5 Tahun 1960 (UUPA)

b. Peraturan Pemerintah Nomor 24 Tahun 1997

c. Bentuk-bentuk Peralihan Hak Atas Tanah

Menurut Peraturan Pemerintah Nomor 24 Tahun 1997 tentang Pendaftaran Tanah, pada Pasal 37 ditentukan bahwa peralihan hak atas tanah dengan cara pemindahan hak dapat terjadi karena beberapa perbuatan hukum, yaitu :

1) Jual Beli

2) Tukar Menukar

3) Pemberian

4) Pemasukan Dalam Perusahaan 
5) Pembagian Hak Bersama

6) Warisan

\section{Tinjauan Umum Mengenai Pemberian}

Pengertian Pemberian secara bahasa atau etimologi adalah pemberian, sedangkan secara istilah atau terminologi adalah akad yang menjadi kepemilikan tanpa terdapat pengganti ketika masih hidup dan juga dapat dilakukan secara sukarela. Pemberian secara umum adalah pemberian (dari seseorang) dengan pengalihan hak milik atas hartanya yang jelas, yang ada semasa hidupnya kepada orang lain. Jika di dalamnya disyaratkan terdapat pengganti yang jelas, maka ia disebut dengan jual beli. Adapun keluarnya harta dengan derma (pemberian) bisa berupa Pemberian, hadiah, dan sedekah. Jika tujuannya adalah untuk mendapatkan pahala akhirat, maka disebut dengan sedekah. Jika dinamakan kasih sayang dan memperat hubungan, maka itu adalah hadiah. Sedangkan jika untuk orang yang diberi, dapat memanfaatkannya, maka dinamakan Pemberian.

Pengertian Pemberian menurut Pasal 1666 Kitab Undang-undang Hukum Perdata, adalah:

"Pemberian adalah suatu perjanjian dengan mana si pemberian, di waktu hidupnya, dengan cuma-cuma dan dengan tidak dapat ditarik kembali, menyerahkan sesuatu benda guna keperluan si penerima Pemberian yang menerima penyerahan itu. Undang-undang tidak mengakui lain-lain Pemberian selain Pemberian-Pemberian di antara orang-orang yang masih hidup."

Dari Pasal 1666 Kitab Undang-undang Hukum Perdata di atas, dapat kita tarik kesimpulan bahwa Pemberian itu mengandung unsur-unsur:

a. Pemberian adalah suatu perjanjian.

b. Pemberian dilakukan pada saat pemberi Pemberian dan penerima Pemberian masih hidup.

c. PengPemberian an dilakukan dengan cuma-cuma dan tidak dapat ditarik kembali.

Pemberian merupakan suatu perjanjian yang tidak dapat ditarik kembali secara sepihak oleh si pemberi Pemberian. Adapun Pemberian wasiat pelaksanaannya dilakukan apabila si pemberi Pemberi meninggal dunia dan dapat ditarik kembali dan dirubah oleh si pemberi Pemberian selama masih hidup. Adapun pengPemberian an tanah tidak boleh melebihi 1/3 bagian dari total keseluruhan harta yang dimiliki. Dan jika melebihi dari 1/3 bagian dari total keseluruhan harta, maka harus mendapatkan persetujuan dari seluruh ahli waris si Pemberian. Dalam Pasal 210 sampai dengan 214 Instruksi Presiden Nomor 1 Tahun 1991 tentang Kompilasi Hukum Islam, disebutkan bahwa :

"Orang yang telah berumur sekurang-kurangnya 21 tahun berakal sehat tanpa adanya paksaan dapat mengPemberian kan sebanyak-banyaknya 1/3 harta bendanya kepada orang lain atau lembaga di hadapan dua orang saksi untuk dimiliki. Harta benda yang diPemberian kan harus merupakan hak dari pemberian. Pemberian dari orang tua kepada anaknya dapat diperthitungkan sebagai warisan. Pemberian tidak dapat ditarik kembali, 
kecuali Pemberian orang tua kepada anaknya. Pemberian yang diberikan pada saat pemberi Pemberian dalam keadaan sakit yang dekat dengan kematian, maka harus mendapat persetujuan dari ahli warisnya. Warga negara Indonesia yang berada di negara asing dapat membuat surat Pemberian di hadapan Konsulat atau Kedutaan Republik Indonesia setempat sepanjang isinya tidak bertentangan dengan ketentuan pasal-pasal ini."

1. Macam dan Syarat Pemberian

2. Subyek dan Obyek Pemberian

3. Cara MengPemberian kan Sesuatu Menurut KUH Perdata

4. Penarikan Kembali Pemberian dalam KUH Perdata.

\section{Peralihan Hak Atas Tanah Melalui Pemberian}

Peralihan hak atas tanah merupakan suatu perbuatan hukum yang bertujuan untuk memindahkan hak dari satu pihak ke pihak lain. Salah satu contoh dari peralihan hak atas tanah adalah melalui Pemberian. Salah satu hak atas tanah yang dapat dialihkan melalui Pemberian adalah Hak Milik. Hak Milik, merupakan hak turun temurun, terkuat dan terpenuh yang dapat dipunyai orang atas tanah, dengan mengingat bahwa hak itu mempunyai fungsi sosial. Apabila sudah dilakukan peralihan hak atas tanah, maka harus segera didaftarkan tanahnya di Kantor Pertanahan atau yang sering disebut dengan pendaftaran tanah.

Suatu hak atas tanah dapat dialihkan atau beralih. Peralihan hak atas tanah tersebut dilakukan oleh pemilik hak atas tanah. Seseorang dikatakan sebagai pemilik hak atas tanah dapat diketahui dari bukti kepemilikan hak atas tanah yang dimilikinya. Bukti kepemilikan hak atas tanah ini dapat diketahui melalui sertifikat hak atas tanah.

Pasal 32 ayat (1) Peraturan Pemerintah Nomor 24 Tahun 1997 tentang Pendaftaran Tanah, disebutkan bahwa : "Sertipikat merupakan surat tanda bukti hak yang berlaku sebagai alat pembuktian yang kuat mengenai data fisik dan data yuridis yang termuat di dalamnya, sepanjang data fisik dan data yuridis tersebut sesuai dengan data yang ada dalam surat ukur dan buku tanah hak yang bersangkutan."

Alat bukti yang kuat sebagaimana dimaksud dalam Pasal 32 ayat (1) dapat diartikan bahwa sepanjang pihak lain tidak dapat membuktikan sebaliknya bahwa dirinya merupakan pemilik sah dari bidang tanah tersebut, maka sertifikat hak atas tanah tersebut harus dianggap sebagai alat bukti yang sempurna.

Pemberian tanah bukan merupakan perjanjian yang pelaksanaannya harus dipenuhi dengan penyerahan haknya secara yuridis kepada yang menerima Pemberian, melainkan merupakan perbuatan hukum yang menyebabkan beralihnya hak milik atas tanah yang bersangkutan kepada penerima Pemberian .

Pasal 1685 Kitab Undang-undang Hukum Perdata ditetapkan bahwa pengPemberian an kepada orang-orang yang belum dewasa yang masih berada dibawah kekuasaan orang tua, barang yang diPemberian kan tersebut harus diterima oleh orang tua yang menguasai penerima Pemberian tersebut. Sama halnya dengan pengPemberian an kepada orang-orang dibawah 
perwalian dan pengampuan, barang yang diPemberian kan tersebut diterima oleh pengampu dengan diberi kuasa oleh Pengadilan Negeri.

Persyaratan pendaftaran peralihan hak karena Pemberian, adalah : ${ }^{1}$

1. Formulir permohonan yang sudah diisi dan ditandatangani pemohon atau kuasanya di atas materai cukup (dengan keterangan bahwa formulir permohonan memuat identitas, luas, letak dan penguasaan tanah yang dimohon, penguasaan tidak sengketa, pernyataan tanah dikuasai secara fisik).

2. Surat kuasa apabila dikuasakan.

3. Fotokopi identitas pemohon/pemegang dan penerima hak (KTP, KK) serta kuasa apabila dikuasakan, yang telah dicocokkan dengan aslinya oleh petugas loket.

4. Sertifikat asli.

5. Akta Pemberian dari PPAT.

6. Izin Pemindahan Hak apabila di dalam sertifikat/keputusannya dicantumkan tanda yang menyatakan bahwa hak tersebut hanya boleh dipindahtangankan jika telah diperoleh izin dari instansi yang berwenang. Contoh izin pemindahan dari peralihan hak atas tanahtanah kegiatan redistribusi tanah (obyek landreform), reforma agraria, tanah-tanah transmigrasi dan lain-lain.

7. Fotokopi SPPT PBB tahun berjalan yang telah dicocokkan dengan aslinya oleh petugas loket.

8. Penyerahan bukti SSB (BPHTB) dan bukti SSP/PPh untuk perolehan tanah lebih dari Rp. 60.000.000,- (enam puluh juta rupiah).

9. Biaya yang dikenakan adalah biaya Pelayanan Pendaftaran Perubahan Nama di dalam PP Nomor 128 Tahun 2015 tentang Jenis dan Tarif Atas Jenis Penerimaan Negara Bukan Pajak yang Berlaku Pada Kementerian Agraria dan Tata Ruang/Badan Pertanahan Nasional. Waktu penyelesaian selama 5 (lima) hari.

\section{PEMBAHASAN}

\section{Pelaksanaan Peralihan Hak Milik Atas Tanah berdasarkan Pemberian Merupakan Solusi Dalam Mengatasi Kelalaian Ahli Waris}

Tanda bukti hak atau SHM adalah pembuktian kepemilikan yang penting, bukti hak tertulis ini sangat berguna untuk menerangkan tentang sesuatu dan tentang kekuatan hukum kepemilikan. Maslaah diawali terbitnya sertifikat tanah, dimana tanah tersebut merupakan peninggalan sebuah kaum. Kaum ini terdiri dari 4 (empat) pihak, dimana 3 (tiga) pihak mengalihkan kepemilikan hak atas tanah mereka melalui jual beli kepada suatu perusahaan pengembang perumahan bersubsidi, tetapi 1 (satu) pihak tidak berkenan mengalihkan kepemilikan hak atas tanahnya dan meminta bukti kepemilikan haknya kepada saudara-saudara satu kaumnya tersebut.

SHM obejk didapati oleh 1 (satu) pihak yang diminta oleh subjek hokum untuk bukti kepemilikan tanah, apabila tidak ada namanya tercantum di dalam SHM maka bukti hak tidak

\footnotetext{
${ }^{1}$ Waskito, Hadi Arnowo., Op.cit., hlm.113
} 
berlaku baginya. Upaya lain untuk menahan laju atau proses kepemilikan dilakukanlah pemblokiran sertifikat tanah ini oleh pihak yang meminta haknya tersebut di Kantor Pertanahan Kota Padang. Pada akhirnya kedua bilah pihak di panggil untuk menyelsaikan secara musywarah, jika mendapatkan kesepakatan di dalam musyawarah tersebut di buat berita acaranya dan diteruskan kepada Notaris/PPAT.

Dikarenakan karena dalam kasus ini ada 3 (tiga) pihak yang merupakan saudara satu kaum sehingga laju proses jual belinya terhambat karena dan terdampak pada pihak pengembang, pengembang tidak bisa melakukan peralihan hak atas tanah di Kantor Pertanahan Kota Padang karena adanya pemblokiran sertifikat tanah. Dikarenakan hal ini menjadi poin penting dalam melaksanakan pembangunan, maka penyelesaiannya haruslah di selesaikan secara simultan.

Adanya kesepakatan antar Kaum tersebut yang dibuat di Kantor Notaris/PPAT akhirnya dibukalah pemblokiran sertifikat tanah oleh pihak yang meminta kepemilikan haknya tersebut. Sertifikat pecahan bagian pihak yang meminta hak kepemilikan tersebut diserahkan kepadanya dengan dibuatkan suatu Akta Kuasa karena tidak melakukan peralihan hak atas tanah di Notaris yang sama, dimana pihak yang meminta hak kepemilikannya ini melakukan peralihan haknya di kantor Notaris/PPATdi Padang, dan 3 (tiga) pihak yang merupakan saudara kaumnya ini tidak bisa menandatangani Akta untuk mengalihkan kepemilikan tanah karena harus segera bergegas keluar kota untuk suatu keperluan dan akan menetap disana.

Salah satu saudara kaumnya menerangkan bahwa dia sebenarnya mau menandatangani Akta untuk peralihan hak kepada saudara satu kaumnya ini tetapi tidak bisa melakukan penandatanganan akta diwaktu dia memberikan sertifikat kepada saudara kaum yang meminta bukti kepemilikan tersebut, karena harus segera pergi hari itu juga ke luar kota disebabkan urusan yang mendesak. Oleh karena itu, mereka mengeluarkan Surat Kuasa saja, agar saudara pihak yang diberikan kuasa bisa melakukan peralihan hak di Notaris/PPAT yang dikehendakinya. Solusi yang mereka ambil untuk mengalihkan kepemilikan adalah dengan jalan perjanjian pura-pura yaitu peralihan hak milik dilakukan melalui Pemberian, dimana merupakan saran yang diberikan baik oleh Notaris/PPAT, untuk mengalihkan hak kepemilikan secara formal walaupun secara kepemilikan sebenarnya memang merupakan milik dari 1 (satu) pihak yang meminta bukti kepemilikannya tersebut, karena namanya tidak dicantumkan dalam sertifikat oleh saudara-saudara satu kaumnya tersebut.

Pemberian yang merupakan solusi dalam mengatasi kelalaian ahli waris dalam memenuhi kewajiban hukumnya, karena dengan adanya kelalaian tersebut hak salah satu ahli waris dari tanah tersebut hilang. Cara pemberian ini, pelaksanaannya sama dengan pelaksanaan Pemberian pada umumnya dimana baik si pemberi maupun si penerima Pemberian melakukannya dengan meminta bantuan jasa Notaris/PPAT. Untuk mengeluarkan Akta Otentik khusus untuk tanah, harus dikeluarkan oleh Pejabat Pembuat Akta Tanah (PPAT). Maka untuk itu, jika pejabat yang didatangi merupakan Notaris tetapi belum mempunyai jabatan sebagai Pejabat Pembuat Akta Tanah (PPAT), maka pejabat yang bersangkutan belumlah mempunyai hak atau tidak berwenang mengeluarkan Akta Otentik untuk tanah, hal ini telah diatur dan diterangkan dalam undang- 
undang yang mengatur tentang jabatan Pejabat Pembuat Akta Tanah (PPAT) yaitu dalam Pasal 1 Peraturan Pemerintah Republik Indonesia Nomor 24 Tahun 2016 tentang Perubahan Atas Peraturan Pemerintah Nomor 37 Tahun 1998 tentang Peraturan Jabatan Pejabat Pembuat Akta Tanah.

Untuk pengPemberian an tanah ini, ketentuan serta syarat-syarat harus dipenuhi oleh para pihak. Dalam Pemberian tanah, harus dituangkan dalam bentuk Akta Pemberian yang dibuat oleh dan di hadapan pejabat yang berwenang, yaitu PPAT. Pejabat Pembuat Akta Tanah (PPAT) meminta syarat-syarat yang diperlukan untuk peralihan hak atas tanah melalui Pemberian ini, antara lain :

1. KTP dan Kartu Keluarga pemberi dan penerima Pemberian (suami dan istri);

2. KTP dan Kartu Kelurga dari seluruh calon ahli waris (pemberi Pemberian );

3. SPT PBB dan bukti bayar 5 (lima) tahun terakhir;

4. NPWP (bila diperlukan);

5. Sertipikat tanah asli;

6. Syarat-syarat lain yang diperlukan, misalnya surat kuasa mengPemberian kan (bila diperlukan);

7. Surat kuasa, jika dikuasakan;

8. KTP kuasa apabila dikuasakan;

9. Surat persetujuan dari calon ahli waris pemberi Pemberian .

Setelah persyaratan telah dilengkapi, kemudian Notaris dan PPAT, melakukan pengecekan sertifikat tanah ke Kantor Pertanahan kota Padang. Apabila tidak bermasalah, maka Kantor Pertanahan kota Padang akan memberi cap atau stempel yang menyatakan bahwa datadata yang ada pada sertifikat tanah tersebut sesuai dengan catatan yang ada pada register atau buku tanah yang ada pada Kantor Pertanahan. Setelah selesai pengecekan sertipikat tanah ini, Notaris dan PPAT melaksanakan penandatanganan akta yang sebelumnya telah dipersiapkan. Penandatanganan akta harus dihadiri oleh para pihak, saksi (paling sedikit dua orang) dan Pejabat Pembuat Akta Tanah (PPAT). Pada saat penandatanganan akta, Pejabat Pembuat Akta Tanah (PPAT) wajib membacakan dan menjelaskan isi akta kepada para pihak apabila ada pihak yang belum jelas, maka Pejabat Pembuat Akta Tanah (PPAT) wajib menjelaskan kembali sampai semua pihak mengerti akan isi akta. Kemudian Pejabat Pembuat Akta Tanah (PPAT) meminta para pihak untuk membayar PPh dan BPHTB. Setelah pajak dibayarkan, tahap selanjutnya, Pejabat Pembuat Akta Tanah (PPAT) melakukan pendaftaran Akta Pemberian tersebut ke Kantor Pertanahan kota Padang, selain itu Pejabat Pembuat Akta Tanah (PPAT) memberitahukan secara tertulis kepada para pihak bahwa Akta Pemberian yang mereka buat sudah dilaporkan dan didaftarkan ke Kantor Pertanahan guna proses balik nama keatas nama penerima Pemberian .

Tata cara atau prosedur pendaftaran permohonan Pemberian di Kantor Pertanahan, yaitu:

1. Syarat-syarat permohonan pendaftaran Pemberian :

a. Surat pengantar;

b. Surat permohonan pendaftaran Pemberian ;

c. Surat kuasa mengurus; 
d. Fotokopi KTP dan Kartu Keluarga pemberi dan penerima kuasa yang dilegalisir;

e. Fotokopi KTP dan Kartu Keluarga pemberi dan penerima Pemberian yang dilegalisir;

f. Fotokopi SPPT PBB dan bukti bayar tahun berjalan yang dilegalisir;

g. Blanko BPHTB dan validasi pajak;

h. Akta Pemberian dan sertifikat tanah.

2. Langkah-langkah pengajuan permohonan ke loket Kantor Pertanahan adalah :

a. Pemohon datang membawa berkas permohonan dan menyerahkan berkas permohonan ke loket pelayanan. Petugas loket pelayanan menerima dan memeriksa kelengkapan dan menguji kebenaran berkas permohonan. Petugas menyampaikan hasil pemeriksanaan berkas yang diajukan, apabila berkas telah benar dan lengkap maka permohonan masuk ke tahap berikutnya.

b. Berkas yang dinyatakan lulus pemeriksaan diajukan ke bagian penerbitan SPS (Surat Perintah Setor). Petugas loket akan membuatkan SPS atas permohonan yang diajukan. SPS berupa keterangan perintah untuk membayar biaya PNBP (Penerimaan Negara Bukan Pajak). Setelah SPS diterima, berkas permohonan tersebut diajukan ke bagian loket pembayaran guna keperluan membayar biaya PNBP.

c. Langkah selanjutnya adalah masuk kepada pencatatan sertifikat tanah.

d. Setelah itu harus ada ijin dari Kantor Wilayah BPN Provinsi dan ijin dari pusat yaitu BPN RI.

e. Setelah mendapatkan ijin selanjutnya penerbitan sertifikat tanah yang untuk selanjutnya diserahkan kepada pemohon.

\section{Kendala-kendala Dalam Proses Peralihan Hak Milik Atas Tanah Yang Dilakukan Melalui Pemberian Sebagai Solusi Dalam Mengatasi Kelalaian Ahli Waris.}

Salah satu penyebab adanya ketidaksesuaian antara kehendak dan pernyataan adalah karena para pihak tidak menginginkan akibat hukum dari apa yang mereka nyatakan. Hal ini kemudian dituangkan ke dalam suatu perjanjian simulasi. Dapat dikatakan bahwa antara para pihak telah terjadi persekongkolan untuk secara diam-diam dan secara sadar melakukan suatu tindakan hukum yang menyimpang dari apa yang seharusnya terjadi.

Pada kantor Notaris dan PPAT, kendala-kendala dalam proses peralihan hak atas tanah melalui Pemberian sebagai solusi dalam mengatasi kelalaian ahli waris dalam memenuhi kewajiban hukumnya ini, yaitu :

1. Nama para pihak di dalam Kartu Tanda Penduduk (KTP) tidak sesuai dengan nama yang tercantum di dalam sertipikat tanah. Untuk hal tersebut di dalam akta nama tersebut harus diterangkan atau dibunyikan. Misalnya nama pemegang sertipikat tanah tertulis AA tetapi di dalam KTP tertulis AA, sehingga di dalam akta dibunyikan pemegang sertipikat tanah atas nama AA dan di dalam KTP atas nama AA. Seharusnya antara nama di dalam sertipikat tanah dengan KTP haruslah sama, jika berbeda dikhawatirkan bukanlah orang yang sama. Dan biasanya untuk melengkapi administrasinya, pihak Badan Pertanahan Nasional kota Padang meminta kelengkapan data yaitu Surat Pernyataan bahwa antara 
nama di sertipikat dengan nama yang di KTP adalah orang yang sama dengan saksi 2 (dua) orang.

2. Tidak adanya Surat Pemberitahuan Pajak Terutang (SPPT) Pajak Bumi dan Bangunan (PBB). Untuk itu para pihak harus melengkapi terlebih dahulu karena menyangkut tentang besarnya Pajak yang harus dibayar, dan juga merupakan syarat administrasi yang harus dilengkapi ke Kantor Badan Pertanahan Nasional Kota Padang.

\section{KESIMPULAN}

Berdasarkan hasil pembahasan, maka penulis dapat mengambil kesimpulan yang merupakan jawaban-jawaban dari permasalahan-permasalahan yang ada, yaitu :

1. Dalam pelaksanaan peralihan hak milik atas tanah melalui Pemberian yang merupakan solusi dalam mengatasi kelalaian ahli waris dalam memenuhi kewajiban hukumnya ini, pada prinsipnya pelaksanaannya sama seperti peralihan hak atas tanah melalui Pemberian pada umumnya. Pelaksanaan peralihan ini merupakan solusi agar hak salah satu ahli waris yang tidak mendapatkan haknya dapat diatasi. Melalui Pemberian inilah, hak kepemilikan akan sertipikat tanah salah satu ahli waris yang merasa dirugikan tersebut dapat dipenuhi dan dapat diproses pendaftaran haknya ke Kantor Pertanahan Nasional kota Padang.

2. Kendala-kendala dalam proses peralihan hak milik atas tanah yang dilakukan melalui Pemberian sebagai solusi dalam mengatasi kelalaian ahli waris dalam memenuhi kewajiban hukumnya ini, awalnya cukup rumit. Ini dikarenakan, adanya salah satu pihak yang tidak bersedia memberikan tanda tangannya dengan berbagai alasan yang pada intinya ingin menguasai tanah tersebut sepenuhnya. Selain itu, adanya beda nama antara nama di KTP dengan di sertifikat tanah dan kekurangan administrasi kelengkapan berkas seperti tidak adanya SPPT PBB yang berguna untuk penghitungan pajak.

\section{DAFTAR PUSTAKA}

Johara T. Jaya Dinata, Tata Guna Tanah dalam Perencanaan, perkotaan, dan Wilayah, ITB, Bandung, 1999, hlm.1

Waskito, Hadi Arnowo, Penyelenggaraan Pendaftaran Tanah di Indonesia, Prenadamedia Group, Jakarta, 2019, hlm. 3.

Peraturan Pemerintah Republik Indonesia Nomor 40 Tahun 1996 tentang Hak Guna Usaha Hak Guna Bangunan Dan Hak Pakai Atas Tanah.

Peraturan Pemerintah Republik Indonesia Nomor 24 Tahun 1997 tentang Pendaftaran Tanah

Undang-undang Dasar Negara Republik Indonesia Tahun 1945.

Undang-undang Republik Indonesia Nomor 5 Tahun 1960 tentang Peraturan Dasar Pokok-pokok Agraria. 